\title{
PÁROS T-PRÓBA PROGRAMOZHATÓ KIALAKÍTÁSA EXCEL VBA KÖRNYEZETBEN
}

\author{
Hampel György
}

\begin{abstract}
Absztrakt: Az Excel táblázatkezelő programmal olyan számolótáblákat tudunk kialakítani, melyeket többször is használhatunk. Egy-egy adat megváltozásakor automatikusan újraszámítódik a teljes tábla. Az adatok megváltoztatását programozott módon is elvégezhetjük a Visual Basic for Application (VBA) szolgáltatás segítségével. Összetett számítások esetén célszerü arra törekedni, hogy a kialakított számolótábla egyszerüen tegye lehetővé a paraméterek értékétől függő eredmények képzését.

Jelen publikáció a páros t-próba automatizált végrehajtása kialakításának egy lehetséges módját tárgyalja. Statisztikai programok nem teszik lehetővé a programozással automatizált kiértékeléseket, ezért az Excel VBA alkalmazása jelentősen felgyorsítja az ismételten elvégzendő számítások előkészítését és végrehajtását. A cikkben bemutatom egy könnyen és kényelmesen használható kezelőfelület elkészítését, valamint a hozzá tartozó VBA programokat.
\end{abstract}

\begin{abstract}
We can create spreadsheets in Excel that can be used several times. When the data changes, the entire table is automatically recalculated. The data change can be done in a programmed method using Visual Basic for Application (VBA). In case of complex calculations, it is advisable to develop a spreadsheet which easily allows producing the results depending on the values of parameters.

This publication discusses a possible way of creating an automated execution of the paired t-test. Statistical programs do not allow automatic evaluations with programming; therefore, the use of Excel VBA significantly speeds up the preparation and execution of calculations that have to be repeated. In this article, I present the preparation of an easy-to-use user interface and the associated VBA programs.
\end{abstract}

Kulcsszavak: Microsoft Excel, VBA, statisztikai kiértékelés, páros t-próba

Keywords: Microsoft Excel, VBA, statistical evaluation, paired t-test

\section{Bevezetés}

Statisztikai kiértékelések során ma már természetes, hogy számítógépet használunk. Viszont ekkor az ismert statisztikai programcsomagokat alkalmazzuk, míg az Excel táblázatkezelö programra ritkán esik a választásunk. Elkerülhetjük a nagyszámú, ismétlődő kiértékelések hosszadalmas, monoton végrehajtását, ha kihasználjuk az Excel nyújtotta programozási lehetőséget a Visual Basic for Application (VBA) szolgáltatással (Fabulya, 2017). Elegendő egy olyan számolótáblát kialakítanunk, melyben automatikusan újraszámítódnak a statisztikai eredmények a kiinduló adatok megváltozásakor (Microsoft, 1995). A VBA programunknak csak a kiértékelendő adatsorok és a keletkező eredmények adatainak cellák közötti mozgatását kell automatizálnia.

A páros t-próbát gyakran alkalmazzuk olyan esetekben, amikor két, egymástól nem független, párokba szervezhető adatokkal rendelkező minták összehasonlítását kell elvégeznünk. A próba elvégzéséhez pár formula kiszámítása szükséges (Michaletzky-Mogyoródi, 1995), melyek könnyen kialakíthatók a számolótáblában.

Az Excel VBA programokat minden olyan területen célszerü alkalmazni, ahol ismétlődő számítási tevékenységek automatizálása megvalósítható (Kovalcsik, 2010). Így pénzügyi befektetések kiértékelésekor (Zsótér-Tóth, 2014), vagy 
adatbázisba szervezett adatok esetén is kényelmesebbé, gyorsabbá teheti munkánkat (Fabulya, 2018).

\section{Anyag és módszer}

Munkánkhoz az Excel 2010 verzióját használtuk. Az alábbiakra tekintettel esett erre a választás:

- Programozási lehetőséget biztosít a Visual Basic for Application bővítményével.

- Az adataink Excel fájlokban érhetők el.

- Egyszerüen kialakíthatjuk a statisztikai kiértékelés számolótábláját munkalapfüggvények alkalmazásával (Wells-Harshberger, 1997).

- A számítógép használók többsége rendelkezik a programmal, ismeri alapvető használatát.

\subsection{Az Excel és VBA bővítménye}

A táblázatkezelő programban egy munkafüzet több lapján alakíthatjuk ki az adatok tárolására és a rajtuk elvégzendő számításokra alkalmas felhasználói felületeket (Zimmerman, 1996). Az automatikus újraszámításokhoz olyan formulákat kell megadnunk, melyek hivatkoznak azokra a cellákra, melyektől az eredmény függ. Az adatok megváltoztathatósága miatt arra is tekintettel kell lennünk a formulák helyes eredménye érdekében, hogy extrém értékek, akár hiányzó adatok mellett is müködjenek.

A VBA bővítmény programozási lehetőséget nyújt. Ezt arra használjuk, hogy automatizáljuk a minták adatainak lecserélését a számolótáblán, valamint az eredmények kigyüjtését táblázatba. Értékadó utasítások szükségesek a cellák és a program változói között az adatok mozgatásához. A programjainkban ciklusok biztosítják a tevékenységek ismétlődő végrehajtását, így az összes minta kiértékelését.

\subsection{A páros t-próba}

A páros t-próba segítségével két, egymástól nem független, adatpárokba szervezhető minták alapján tesztelhetjük két statisztikai sokaság várhatóértékei közötti relációra vonatkozó hipotézis helyességét. Az adatoknak intervallum skálán mérhető, numerikus adattípusú kell lennie. Az alkalmazhatóságának feltétele, hogy normális eloszlásúnak legyen tekinthető a két populáció (Móri, 2011).

A próba végrehajtásakor először kiszámítjuk az alkalmazott statisztikai függvény (1) értékét $(t)$ a minta adatsorából.

$$
d_{i}=x_{i}-y_{i} \quad \bar{d}=\frac{1}{n} \sum_{i=1}^{n} d_{i} \quad t=\frac{\bar{d}}{\frac{s}{\sqrt{n}}} \quad s=\sqrt{\frac{\sum_{i=1}^{n}\left(d_{i}-\bar{d}\right)^{2}}{n-1}}
$$

ahol:

$x_{i}, y_{i}$ - a minták i. elempárja $(\mathrm{i}=1, \ldots, \mathrm{n})$,

$s-$ a becsült szórás,

$\bar{d}$ - a mintaelemek különbségének átlaga, (számtani közép),

$n$ - a minta elemszáma. 
A döntést két technikával is meghozhatjuk:

- kritikus tartomány alapján,

- $\quad$ szignifikanciaszint $(p)$ kiszámításával.

Amikor a döntést a kritikus tartománnyal hozzuk meg, akkor a statisztikai függvény értékét hasonlítjuk össze a tartomány szélét mutató értékkel, mely a Student-féle t-eloszlás eloszlásfüggvényének értéke, mint kritikus érték $\left(t_{k r}\right)$, mely függ a minta elemszámától $(n)$ és az elsőfajú hibavalószínüségtől $(\varepsilon)$. Ha a kritikus tartományba esett a statisztikai függvény értéke, akkor a két populáció várhatóértékének szignifikáns, jelentős eltérését jelzi a próba. Szintén ez adódik, ha a szignifikanciaszint kisebb az elsőfajú hibavalószínüségnél, azaz $p<\varepsilon$ (Móri, 2011).

\section{Eredmények és értékelésük}

Két munkalapot kell kialakítanunk az Excelben ahhoz, hogy a felhasználó csak a saját adatainak szerkesztését tudja elvégezni az egyiken, míg a számításokért felelös munkalap ne legyen szerkeszthető. Viszont így ezek a munkalapok „kommunikálnak” egymással, hiszen a felhasználói felület munkalapjának adatait dolgozza fel a számítások munkalapja, míg a számítások eredménye megjelenik a felhasználói felületen.

\subsection{Számítások munkalapja}

A számítások munkalap a felhasználó számára rejtett, így nem szükséges nagy hangsúlyt fektetnünk az esztétikus, felhasználóbarát megjelenítésre. Meg kell oldanunk, hogy csak a számítások során értelmezhető, numerikus adatok kerüljenek át a kezelő felület munkalapjáról. Ez megoldható az Excel munkalap függvényeivel a (2) képlet szerint.

$$
\text { =HA(SZÁM(Adatok!A3);Adatok!A3;"") }
$$

A $H A($ () munkalapfüggvény a $S Z A ́ M()$ függvénnyel ellenőrzi, hogy az adatkezelő felület Adatok munkalapján az A3 cella tartalma szám vagy sem. Így csak numerikus érték kerül át a számítások munkalapra. E képlet másolatai eredményezik, hogy a rejtett munkalapra helyezzük az adatokat az $A 2$ cellától kezdődően. A számítások már csak ezeken az adatokon alapulnak. Mivel ezek munkalapfüggvények, ezért automatikusan megjelenik minden adatváltozás a számítások lapján.

Az elsőfajú hibavalószínüség (D3 cella), valamint a vizsgálandó hipotézis típusa (D5 cella) szükséges még a számítások elvégzéséhez. Ezek ellenőrzés nélkül vehetők át az Adatok munkalapról, mert ott hibás értéket nem fogad el a program a felhasználótól. A számításkor a hipotézis típusa három féle lehet attól függően, hogy milyen irányú eltérést vizsgálunk a két sokaság várhatóértéke között:

- kétszélü $\left(m_{1} \neq m_{2}\right)$,

- balszélü $\left(m_{1}<m_{2}\right)$,

- jobbszélü $\left(m_{1}>m_{2}\right)$. 
A felhasználó a vizsgálandó hipotézis megfogalmazásakor tetszőleges relációs jeleket alkalmazhat, de a számítás technikája a fenti típusú ellenhipotézisek (alternatív hipotézisek) egyikére vezet. Az 1. táblázatban látható, hogy a lehetséges felhasználó által vizsgálandó hipotézis (H) típusok esetén a számításkor melyik alternatív hipotézist $\left(\mathrm{H}_{\mathrm{A}}\right)$ kell alkalmazni, és milyen döntést kell hozni H-ra, amikor az alternatív hipotézist kell elfogadni, vagyis amikor a számított szignifikanciaszint kisebb az elsőfajú hibavalószínűségnél $(p<\varepsilon)$.

\section{1. táblázat: Döntés az alkalmazott alternatív hipotézis elfogadásakor}

\begin{tabular}{|c|c|c|}
\hline $\mathrm{H}$ & $\mathrm{H}_{\mathrm{A}}$ & Döntés $\mathrm{H}_{\mathrm{A}}$ elfogadásakor \\
\hline$m_{1}=m_{2}$ & $m_{1} \neq m_{2}$ & H elutasítva \\
\hline$m_{1} \neq m_{2}$ & $m_{1} \neq m_{2}$ & H elfogadva \\
\hline$m_{1}<m_{2}$ & $m_{1}<m_{2}$ & H elfogadva \\
\hline$m_{1} \leq m_{2}$ & $m_{1}>m_{2}$ & H elutasítva \\
\hline$m_{1}>m_{2}$ & $m_{1}>m_{2}$ & H elfogadva \\
\hline$m_{1} \geq m_{2}$ & $m_{1}<m_{2}$ & H elutasítva \\
\hline
\end{tabular}

Forrás: A szerző saját szerkesztése.

A számítások során egy-egy cellában a következő értékek alakulnak ki:

- a minta elemszáma $(n)$,

- a mintaelemek különbségének átlaga $(\bar{d})$,

- a szórás becsült értéke $(s)$,

- a statisztikai függvény értéke $(t)$,

- a kritikus tartomány határa $\left(t_{k r}\right)$,

- a próba szignifikanciaszintje $(p)$.

Ezek mindegyike munkalapfüggvényekkel kapható meg:

- DARAB(),

- ÁTLAG(),

- SZÓRÁS(),

- T.INVERZ(),

- T.ELOSZL().

A kritikus tartomány határának, valamint a szignifikanciaszintnek a kiszámításakor azt is figyelembe kell venni, hogy melyik típusú ellenhipotézist alkalmazzuk.

A felhasználói felület felé a legfontosabb eredmény a szignifikanciaszint $(p)$, melyböl könnyen adódik az eredmény a különböző típusú hipotézisek esetén.

\subsection{Felhasználói felület kialakítása}

Minden adatváltozáskor az Adatok munkalapon a számítások automatikusan aktualizálódnak, mivel a számítások munkalapon csak Excel munkalap függvényeket alkalmaztunk. Ez azt jelenti, hogy elegendő csak az Adatok munkalapot olyan felhasználói felületté alakítani, ahol az adatbevitel és az eredmény megjelenítése valósul meg. A kész felület látható az 1. ábrán. 
A próba eredményét három módon is megjelenítjük egy-egy bekeretezett részben:

- szövegesen,

- $\quad$ egy + vagy - jellel,

- a szignifikancia szinttel.

\section{1. ábra: A páros t-próba felhasználói felülete}

\begin{tabular}{|c|c|c|c|c|c|}
\hline \multicolumn{6}{|c|}{ Páros t-próba } \\
\hline \multicolumn{2}{|c|}{ Adatok } & \multicolumn{2}{|c|}{ Elsőfajú hibavalószínűség $(\varepsilon)$} & \multicolumn{2}{|c|}{0,05} \\
\hline 48,2 & 51,1 & & & & \\
\hline 48,9 & 50,2 & \multicolumn{2}{|c|}{ Hipotézis várhatóértékre } & \multicolumn{2}{|c|}{$m_{1}-m_{2}=m=0$} \\
\hline 49,2 & 50,5 & & & & \\
\hline 50,2 & 49,2 & & & & \\
\hline 48,9 & 49,6 & \multicolumn{2}{|l|}{ A próba eredménye: } & \multirow{3}{*}{$\rightarrow$} & \\
\hline 51,3 & 49,9 & \multicolumn{2}{|c|}{$A z m_{1}-m_{2}=m=0$ hipotézis elfogadható. } & & + \\
\hline 49,7 & 48,8 & \multirow[t]{3}{*}{ Szignifikancia szint: } & 0,13733 & & \\
\hline 50,3 & 50,9 & & & & \\
\hline 48,3 & 51,6 & & & & \\
\hline
\end{tabular}

Forrás: A szerző saját szerkesztése.

Az ábrán látható, hogy a vizsgálandó hipotézis egyszerübb formájú, ha bevezetjük a két várhatóérték helyett a különbségüket $\left(m=m_{1}-m_{2}\right)$. A döntéshez csak a szignifikanciaszint értéke szükséges a számítások eredményeként, melyet az elsőfajú hibavalószínüséggel hasonlítunk össze. Az alternatív hipotézist fogadjuk el, ha teljesül a $p<\varepsilon$ feltétel.

A felhasználónak adatok módosítására a világos hátterủ cellák esetén van csak lehetősége. Megadható a két minta adatsora, az elsőfajú hibavalószínüség, valamint a hipotézis típusa. A munkalap védelmét bekapcsolva, és a védendő cellákat zároltra állítva érhetjük el, hogy a munkalapon a felhasználó csak a többi cellát módosíthassa.

Érvényesítési beállításokkal védekezhetünk nem értelmezhető adatok ellen. Az elsőfajú hibavalószínüség értéke leggyakrabban 0,01 vagy 0,05 szokott lenni. Itt a 2 . ábrán látható érvényesítési beállítás miatt csak 0 és 0,2 közötti érték adható meg.

\section{2. ábra: Adatérvényesítés üzenetei}

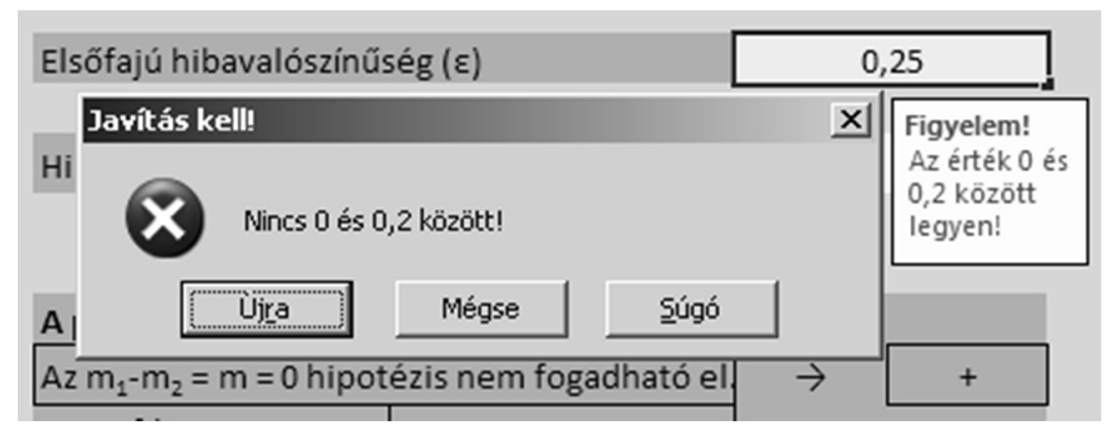

Forrás: A szerző saját szerkesztése. 
Amikor ráállunk erre a cellára, megjelenik a tájékoztató figyelmeztetés, míg hibás adat esetén hibaüzenet is látható.

A legördülö listás adatérvényesítés (3. ábra) biztosítja, hogy a hipotézis típusaként csak az értelmezhető relációk egyike legyen kiválasztható.

\section{3. ábra: Legördülő listás adatérvényesítés}

\begin{tabular}{|c|c|c|}
\hline \multirow[t]{3}{*}{ Hipotézis várhatóértékre } & $m_{1}-m_{2}=$ & $\mathrm{m}=0$ \\
\hline & & $m=0$ \\
\hline & & $m \neq 0$ \\
\hline A próba eredménye: & & $m \leq 0$ \\
\hline Az $m_{1}-m_{2}=m=0$ hipotézis elfogadható. & $\rightarrow$ & $m \geq 0$ \\
\hline
\end{tabular}

Forrás: A szerző saját szerkesztése.

\subsection{Kiértékelések automatizált végrehajtása}

A páros t-próbát több minta adatsorán automatikusan végrehajthatjuk az Excel VBA programozási lehetőségével. Amennyiben egy munkalapon (Adatsorok) több páros t-próba adatait szerepeltetjük szisztematikus, algoritmizálható elrendezésben, akkor itt a kiértékelés eredményeket is megkaphatjuk egy adatként, például + vagy - jelzés formájában. A programban ciklus szerkezetre van szükségünk. A ciklusban azt kell leprogramoznunk egy minta adatsor hipotézisének kiértékeléséhez, hogy az adatok átkerüljenek a felhasználói felület munkalapjára (Adatok), majd az ott adódó eredményt kiolvasva, a döntés eredményét helyezzük az erre a célra fenntartott cellába.

Az Adatsorok munkalap a következő szerkezetü:

- két oszlopban helyezkedik el egy kiértékelendő mintapár, mellettük a következő párok,

- az első oszlop első cellája az elsőfajú hibavalószínüség,

- a második oszlop első cellája a hipotézis típusa,

- az első oszlop második cellája az eredmény számára fenntartott cella,

- a két oszlop harmadik cellájától a két minta adatsora következik.

A program a következö:

Public Sub kiertekeles()

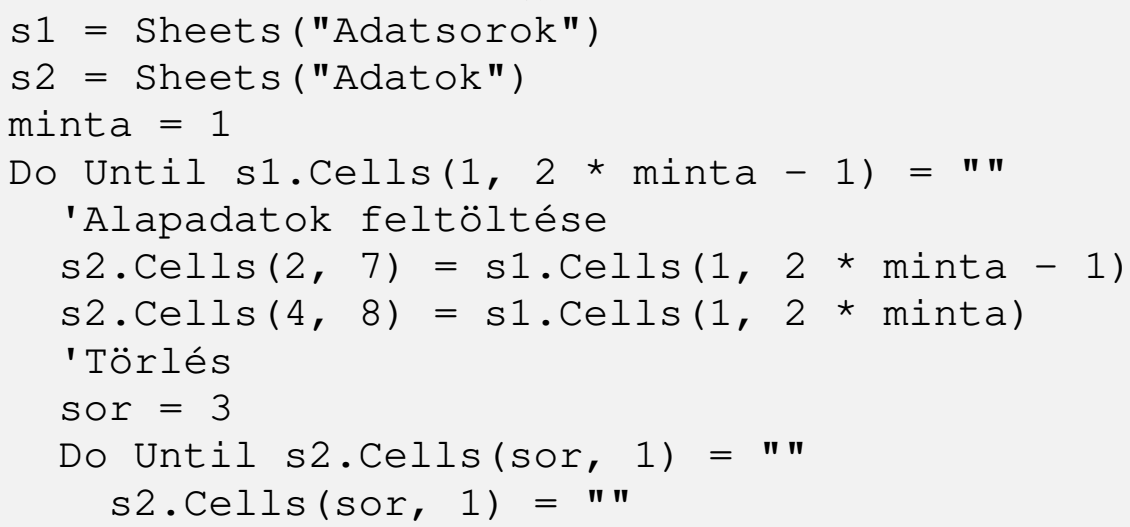




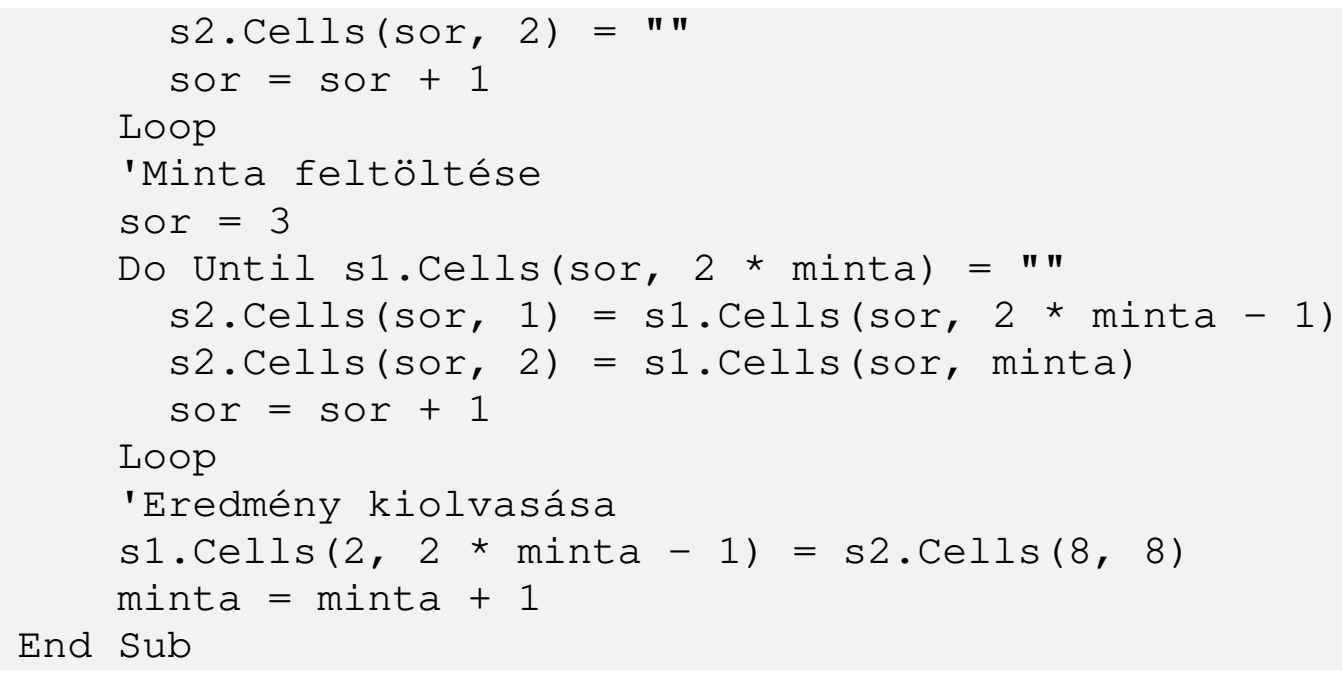

Az adatok áthelyezése az $s 1$ és $s 2$ változókkal elérhető Adatsorok és Adatok munkalapok cellái között történik. Az első mintától (minta=1) kezdődik a végrehajtás, mely akkor ér véget, mikor az aktuális oszlop üres cellával nem kezdődik (do until sl.cells(1,2*minta-1)=””). Egy cikluson belül elöször az alapadatokat helyezzük át, majd a minta adatsorát, de előbb törölni kell, mert bár egy újabb adatsor felülírja az előzőt, de ha az aktuális rövidebb, akkor a maradék adatok hamis eredményt okoznának. A ciklus végén kiolvassuk az eredményt és átállunk a következő minta oszlopára (minta=minta +1$)$.

\section{4. Összegzés}

Automatizálni tudtuk a páros t-próba számításinak végrehajtását. Kialakítottuk azt a felhasználóbarát felületet, melyen egyszerủen beállítható minden adat, s megjeleníti a próba eredményét. Programozott módon is kialakítottuk az újbóli felhasználást a Visual Basic for Application szolgáltatással. Ehhez rendelkeznünk kell minimális szintü VBA programozói ismeretekkel.

\section{Irodalomjegyzék}

Fabulya Z. (2017): Hőkezelési folyamatok összehangolása Excel VBA szolgáltatásokkal. Jelenkori társadalmi és gazdasági folyamatok, 12 (4): 19-25.

Fabulya Z. (2018): Access alkalmazás kialakítása ügyfélközpontú szolgáltatások nyilvántartására. Jelenkori Társadalmi és Gazdasági Folyamatok, 13 (1-2): 67-76.

Zsótér B., Tóth A. (2014): Examination of statisfaction related to investments (2006-2011) accomplished by the local council in Abony. Analecta Technica Szegedinensia 8 (1): 33-37.

Michaletzky Gy., Mogyoródi J. (1995): Matematikai statisztika. Nemzeti Tankönyvkiadó, Budapest.

Kovalcsik G. (2010): Az Excel programozása. Computerbooks, Budapest.

Microsoft Press (1995): Microsoft Excel/Visual Basic Programmer's Guide. Microsoft Press, Washington.

Móri T. (2011): Statisztikai hipotézisvizsgálat. Typotex Kft., Budapest.

Wells E., Harshberger S. (1997): Microsoft Excel 97 Developer's Handbook. Microsoft Press, Washington.

Zimmerman M. W. (1996): Microsoft Office 97/Visual Basic Programmer's Guide. Microsoft Press, Washington. 